\title{
PENANAMAN KARAKTER POSITIF PELAJAR MELALUI PEMBAHASAN FENOMENA-FENOMENA FISIKA DAN PENDEKATAN ANALOGI (HASIL KAJIAN PERKULIHAN FISIKA DASAR)
}

\author{
Joni Rokhmat \\ Program Studi Pendidikan Fisika \\ Universitas Mataram \\ Mataram, Indonesia \\ Email : joni.fkip.unram@gmail.com
}

\begin{abstract}
The discussion results of Fundamental Physics I lecturing, especially the $1^{\text {st }}$ Newton law about movement, law of Lenz, electromagnetic induction, and law of Bernoulli about pressure of flowing fluid show that in the concepts implicitly there is an action-reaction relation between objects. We could analogize these phenomena to the interaction between human being, in the contex of learning we can analogize it to the interaction between educator and students. When the interaction between objects softly occurs ("persuasive") the reaction is not emerge but when it happen quictly the reaction emerges and it against the change caused by the action. The implementation of the discussion of Physics concept and analogy approach usefull to implant positive characters to the students. The positive characters include honesty, responsibility, respect, empaty, self restraint, modesty, patient, no despondently, diligent, love, and good samaritan, also make the values to be a habit in the mind, feeling, and in action.
\end{abstract}

Kata kunci: Physics concept discussion, Analogy approach, Positive character of students.

\section{Pendahuluan}

Sejumlah perilaku atau karakter negatif terjadi dalam dunia pendidikan, perilaku tersebut antara lain berwujud perkelahian antar pelajar SMU maupun mahasiswa. Dari tahun ke tahun jumlah perkelahian dan korban cenderung meningkat, bahkan sering tercatat dalam satu hari terdapat sampai tiga perkelahian di tiga tempat sekaligus. Menurut Bimmas Polri Metro Jaya pada tahun 1992 tercatat 157 kasus perkelahian pelajar, tahun 1994 meningkat menjadi 183 kasus dengan menewaskan 10 pelajar, tahun 1995 terdapat 194 kasus dengan korban meninggal 13 pelajar dan 2 anggota masyarakat lain. Sementara itu, tahun 1998 ada 230 kasus yang menewaskan 15 pelajar serta 2 anggota Polri, dan tahun berikutnya korban meningkat dengan 37 korban tewas (Kompas, 2009).

Dinas Pendidikan DKI telah berhasil melacak kelompok-kelompok siswa yang kerab melakukan tawuran dan kekerasan. Berikut daftar 15 kelompok/geng sekolah di Jakarta yang berhasil dilacak oleh Pemprov DKI. Kelimabelas geng tersebut: (1) SMA 3: Residivis; (2) SMK 29 Penerbangan: Kapal; (3) SMA 46: Texas 46; (4) SMA 63: Pulverize 63; (5) SMA 60: Psycho60; (6) SMA 86: Grunge86; (7) SMA 87: Rasta87; (8) SMK 32: Spt32; (9) SMA 90: Neunzig90; (10) SMA 82: Patra82; (11) SMA 70: Vallenty70; (12) SMA 6: Gorasix6; (13) SMA 74: Artileri74; (14) SMA 1 Budi Utomo: Boedoet 45; Dan (15) SMA 8: (namanya belum terdeteksi) (Kompas, 2014).

Peluncuran kurikulum 2013 merupakan salah satu upaya menekan perilaku negatif yang ada dan menekan kemungkinan tumbuhnya perilaku tersebut pada para pembelajar yang sedang menempuh pendidikan. Upaya-upaya menekan karakkter negatif ini, sebut saja secara formal dimulai dengan diterapkannya kurikulum 2013, telah secara besarbesaran disuarakan dalam lingkungan pendidikan formal tetapi hingga kini hasilnya belum terlihat. Aspek pembentukan karakter positif dalam konsep kurikulum 2013 pada jenjang pendidikan dasar mendapat porsi lebih dari $50 \%$, selanjutnya pada jenjang pendidikan yang lebih tinggi porsi ini berkurang, mulai sekitar $45 \%$ (SLTP), antara $25 \%$ $33 \%$ (SLTA), dan sekitar $15 \%$ pada jenjang Pendidikan Tinggi (Kosasih, 2014).

Menekan kemunculan karakter negatif dapat dilakukan dengan menanamkan karakter positif. Konsep kurikulum 2013, dalam menanamkan karakter positif kepada pembelajar dilakukan secara terintegrasi dengan proses pembelajaran. Zubaedi (2012) menyatakan bahwa karakter dapat dibentuk melalui pendidikan karena pendidikan merupakan alat paling efektif untuk menyadarkan individu dalam jati diri kemanusiaannya. Selain itu, pendidikan, dibanding faktor lain, memberi dampak dua atau tiga kali lebih kuat dalam pembentukan kualitas manusia.

Berdasar pada dua hal di atas agar setiap pengajar (dosen maupun guru) diharapkan mampu mengintegrasikan proses pembelajaran materi yang menjadi ganggung-jawabnya dengan penanaman karakter positif kepada pembelajar. Sesuai dengan latar belakang penulis (bidang pendidikan fisika), dalam tulisan ini dibahas bagaimana menanamkan 
karakter positif kepada pembelajar melalui pembahasan fenomena-fenomena fisika dalam proses pembelajaran. Namun demikian, untuk menyatukan pengertian karakter positif, dalam tulisan ini dibahas pula pengertian karakter. Selain itu, mengingat keterbatasan ruang, uraian fenomena fisika berkenaan dengan penanaman karakter positif dibatasi pada beberapa konsep fisika saja seperti hukum kelembaman atau hukum I Newton tentang gerak, hukum Lenz, induksi elektromagnetik, dan hukum Bernoullai tentang tekanan pada fluida yang mengalir.

\section{Pembahasan}

\section{A. Pengertian Karakter Positif}

Wynne (1991) dalam Mulyasa (2012) mengemukakan bahwa karakter berasal dari Bahasan Yunani yang berarti "to mark' (menandai) dan berfokus pada bagaimana menerapkan nilai-nilai kebaikan dalam tindakan nyata atau prilaku seharihari. Pernyataan ini dapat diinterpretasikan diperlukan strategi-strategi menerapkan nilai-nilai kebaikan. Berkenaan dengan lingkungan pendidikan strategi tersebut merupakan cara-cara yang harus dilakukan pengajar untuk menanamkan nilai-nilai itu secara terintegrasi dalam pembelajaran.

Mulyasa (2012) menyatakan bahwa karakter merupakan sifat alami seseorang dalam merespon situasi secara bermoral yang diwujudkan dalam tindakan nyata melalui perilaku baik, jujur, bertanggung jawab, hormat terhadap orang lain, dan nilai-nilai karakter mulia lainnya. Sementara, Zubaedi (2012) menyatakan bahwa karakter merupakan mustika hidup yang membedakan manusia dengan binatang. Manusia tanpa karakter adalah manusia yang sudah "membinatang".

Lembaga formal di negara kita, Pusat Bahasa Depdiknas mengartikan karakter sebagai "bawaan, hati, jiwa, kepribadian, budi pekerti, prilaku, personalitas, sifat, tabiat, temperamen, watak" (Kemdiknas, 2010). Sementara Dirjen Pendidikan Agama Islam, Kementerian Agama Republik Indonesia (2010) mangartikan karakter sebagai totalitas ciri-ciri pribadi yang melekat dan dapat diidentifikasi pada prilaku-prilaku individu yang bersifat unik, yaitu secara khusus ciri-ciri ini membedakan membedakan satu individu dengan individu lainnya.

Komponen karakter: Zubaedi (2012) menyatakan bahwa karakter tersusun atas tiga bagian yang saling berhubungan, yaitu: pengetahuan moral (moral knowing), perasaan moral (moral feeling), dan perilaku moral (moral behavior) sedangkan Lickona (1992) dalam Mulyasa (2012) membagi karakter positif menjadi: (1) Pengetahuan tentang moral (moral knowing); (2) Perasaan tentang moral (moral feeling); dan (3) Tindakan moral (moral action).

Karakter positif: Tiga komponen positif sebagaimana dikemukakan Lickona (1992) di atas, dua komponen pertama memiliki kaitan sebagai berikut: (1) Moral knowing berkaitan dengan kesadaran, pengetahuan nilai, pandangan, penalaran, keputusan, dan self-knowledge; (2) Moral feeling berkaitan dengan kata hati, rasa harga diri, empati, cinta kebaikan, pengendalian-diri, dan kerendahan hati. Sementara itu, moral action merupakan perpaduan dari moral knowing dan moral feeling yang diwujudkan dalam kompetensi keinginan dan kebiasaan. Zubaedi (2012) menyatakan bahwa karakter baik terdiri atas pengetahuan tentang kebaikan, keinginan terhadap kebaikan, dan berbuat kebaikan. Dalam hal ini diperlukan pembiasaan dalam pemikiran, pembiasaan dalam hati, dan pembiasaan dalam tindakan. Terakhir, Mulyassa (2012) mengemukakan karakter baik (mulia) meliputii prilaku jujur dan suka menolong.

Berdasar pada beberapa pengertian dan komponen karakter positif dalam uraian di atas dan ditambah gagasan penulis, dalam tulisan ini karakter positif diartikan sebagai pengetahuan, kesadaran, dan penerapan nilai-nilai yang meliputi kejujuran, tanggung-jawab, rasa hormat terhadap orang lain, empati, pengendalian diri, kerendahan hati, kesabaran, pantang putus asa, tekun, kecintaan terhadap lingkungan sekitar, dan suka menolong, serta menjadikan nilai-nilai sebagai pembiasaan dalam pemikiran, perasaan, dan dalam tindakan. Berkenaan dengan pembelajarn fisika, pembelajar diharapkan mempu mengembangkan karakter positif tersebut melalui proses pembahasan fenomena-fenomena fisika.

\section{B. Pengertian Pendekatan Analogi}

Podolefsky (2004) menyebutkan beberapa contoh pasangan analogi esensial dalam fisika, seperti hukum Coulomb dengan hukum gravitasi, medan listrik dengan medan suhu, energi yang tersimpan dalam kapasitor dengan yang tersimpan dalam pegas, aliran aurs listrik dengan aliran air dalam pipa, dan sebagainya. Artinya, untuk memudahkan pembahasan suatu konsep dapat dilakukan dengan menganalogikan konsep itu dengan konsep lain yang sudah dikenal atau dipahami lebih baik atau dengan konsep lain yang lebih kongkrit. Kemiripan pasangan konsep yang dijadikan analogi dapat dilihat dalam Halliday \& Resnick (1978), Tipler \& Mosca (2008), Gordon, dan McGrew, \& Serway (2010).

Dalam tulisan ini penulis mengartikan pendekatan analogi untuk pembelajaran fisika sebagai penggunaan objek atau cara lain yang dipandang lebih dikenal dan lebih mudah dipahami dalam menjelaskan suatu masalah atau untuk menjembatani analisis konsep-konsep fisika kedalam pembahasan 
karakter. Pembahasan dalam tulisan ini, benda atau besaran-besaran fisika dianalogikan sebagai benda lain atau sebagai seseorang. Penganalogian ini lebih diorientasikan agar pembaca lebih mudah memahami kaitan antara analisis fenomena-fenomena fisika dengan nilai-nilai dari karakter positif tersebut.

\section{Pengembangan Karakter Positif melalui Pembelajaran Fisika}

Sebelum secara rinci menguraikan kaitan fenomena fisika dalam pembelajaran dan karakter positif penulis ingin menguraikan diingat fenomena populer berikut: Dalam suatu gua, pada langit-langit terdapat sumber air cukup kecil sehingga air itu keluar setetes demi setetes tetapi hal ini berlangsung sangat lama dan tetesan air tersebut jatuh tepat di atas satu titik pada batu besar yang semula berbentuk bulat utuh. Setelah puluhan tahun terkena tetesan air, batu menjadi berlubang cukup dalam.

Fenomena tersebut menggambarkan bahwa air yang secara rasional tidak mungkin digunakan untuk melubangi batu, ternyata jika usaha itu dilakukan secara berulang dan terus menerus ternyata akhirnya batu itu menjadi berlubang. Fenomena ini termasuk fenomena fisika dapat diinterpretasikan bahwa jika manusia tekun dan tanpa putus asa, serta terus berusaha untuk mendapatkan sesuatu yang diinginkan pada akhirnya keinginan tersebut dapat tercapai.

Penggunaan paradigma gaya gesek sebagai gayareaksi dan pendekatan analogi dapat memperbaiki konsepsi salah mahasiswa berkenaan syarat kemunculan, penentuan jenis, arah, dan nilai untuk gaya gesek (Rokhmat, 2014). Pembahasan ini berfokus pada fakta bahwa benda-benda di sekitar kita memiliki sifat reaktif. Apabila konsep ini digunakan pada konsep-konsep fisika, sepengetahuan penulis secara umum pambahasan konsep-konsep tersebut menjadi lebih mudah jika didasarkan pada konsep reaksi. Jika pola berfikir pendekatan di atas dibalik, melalui pembahasan berbagai fenomena fisika dalam suatu pembelajaran kita dapat menanamkan karakter positif kepada pembelajar.

\section{Respon "Positif" Benda terhadap Stimulus Persuasif}

Benda-benda di alam pada dasarnya memiliki kemampuan merespon secara "positif" atau "negatif" terhadap suatu stimulus atau tindakan atau aksi. Terhadap stimulus atau tindakan atau aksi yang bersifat radikal atau penulis menamakannya sebagai stimulus "negatif" benda-benda akan memberi respon "negatif" pula. Sementara itu, jika stimulus itu bersifat persuasif atau penulis menamakannya sebagai stimulus "positif" benda-benda akan memberi respon "positif" pula. Namun demikian, berbentuk apakah stimulus atau tindakan atau aksi "negatif" atau "positif" tersebut? Apa pula contoh-contoh fenonena yang terkait?
Berdasarkan pengalaman dalam proses pembelajaran fisika, penulis mengidentifikasi bahwa beberapa fenomena fisika dapat dijadikan sebagai wahana untuk memperlihatkan kemampuan benda memberi respon "positif" ketika suatu stimulus persuasif diberikan atau dikenakan pada benda tersebut. Fenomena-fenomena tersebut seperti hukum kelembaman atau hukum I Newton tentang gerak, hukum Lenz, dan induksi elektromagnetik.

\section{a. Hukum I Newton atau Hukum Kelembaman}

Perhatikan peristiwa terkait dengan kelembaman untuk suatu dua balok identik $A$ dan $B$ yang digantung dengan tali $a_{1}$ dan $b_{1}$, serta di bagian bawah balok itu digantungkan tali $a_{2}$ dan $b_{2}$, diketahui keempat tali itu identik dan berpanjang sama. Selanjutnya, ujung bawah tali $a_{2}$ dan $b_{2}$ masingmasing ditarik dengan gaya $F_{\mathrm{a}}$ dan $F_{\mathrm{b}}$ berarah ke bawah. Perbedaan antara $F_{\mathrm{a}}$ dan $F_{\mathrm{b}}$ adalah bahwa $F_{\mathrm{a}}$ merupakan gaya hentakan cukup besar sedangkan $F_{\mathrm{b}}$ merupakan gaya yang pada mulanya kecil tetapi semakin lama semakin besar. Sementara itu kesamaan tarikan gaya $F_{\mathrm{a}}$ dan $F_{\mathrm{b}}$ adalah bahwa pada akhirnya di antara tali $a_{1}$ dan $a_{2}$ atau antara tali $b_{1}$ dan $b_{2}$ ada yang putus (Gambar 1). Pertanyaannya adalah di antara dua kelompok tali itu yang mana akan terputus?

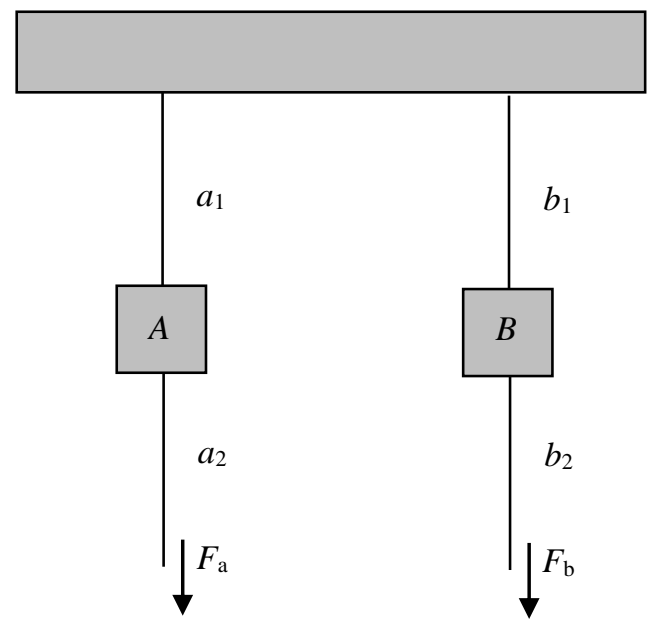

Gambar 1. Fenomena Fisika Balok $A$ dan $B$ terkait dengan Hukum Kelembaman

Untuk menjawab pertanyaan di atas dapat didasarkan pada hukum kelembaman, yaitu bahwa ketika keadaan balok ingin diubah secara tiba-tiba (fenomena balok $A$ ) maka balok itu cenderung untuk mempertahankan keadaannya tetapi jika upaya perubahannya dilakukan secara perlahan (fenomena balok $B$ ) balok itu cenderung untuk berubah. Jadi berdasar pada alasan tersebut, pada fenomena balok $A$ 
tali $a_{2}$ yang putus tetapi pada fenomena balok $B$ tali $b_{1}$ yang putus ((Halliday \& Resnick, 1978), (Tipler \& Mosca, 2008), (Gordon, dan McGrew, \& Serway, 2010)). Pendekatan analogi: Jika penjelasan di atas dilakukan penganalogian balok $A$ dan $B$ sebagai orang (orang pertama), gaya $F_{1}$ dan $F_{2}$ sebagai ajakan orang lain (orang kedua), dan pergerakan balok ke bawah sebagai kegiatan orang pertama dan kedua pergi bersama-sama, maka fenomena dapat dijelaskan seperti pada alinea berikutnya

Fenomena balok $A$ : Pada fenomena ini dapat dianalogikan bahwa orang pertama sedang duduk bersantai di rumah. Beberapa saat kemudian, secara tiba-tiba datang orang kedua mengajak orang pertama untuk pergi meninggalkan rumahnya ke tempat lain tetapi saat mengajak, orang kedua tersebut secara memaksa dan tidak memberi penjelasan atau alasan mengapa orang pertama itu harus pergi meninggalkan rumahnya. Dengan kondisi ini, orang pertama cenderung untuk tidak mau menuruti ajakan orang kedua.

Fenomena balok $\boldsymbol{B}$ : Pada fenomena ini dapat dianalogikan bahwa orang pertama sedang duduk bersantai di rumah. Beberapa saat kemudian, datang orang kedua mengajak orang pertama untuk pergi meninggalkan rumahnya ke tempat lain tetapi saat mengajak, orang kedua tersebut lebih dulu memberi penjelasan yang masuk akal mengapa orang pertama tersebut harus pergi meninggalkan rumahnya. Dengan kondisi ini, orang pertama akhirnya sepakat menuruti ajakan orang kedua.

Penanaman karakter yang terkait: Berdasar fenomena di atas, balok $A$ cenderung menolak untuk diubah secara paksa tetapi balok $B$ mau untuk mengubah keadaannya. Tali $a_{2}$ yang putus menunjukkan bahwa tali $a_{2}$ mengalami tegangan lebih besar daripada tali $a_{1}$. Sementara itu, tali $b_{1}$ yang putus menunjukkan bahwa tali $b_{1}$ mengalami tegangan lebih besar daripada tali $b_{2}$ ((Halliday \& Resnick, 1978), (Tipler \& Mosca, 2008), (Gordon, dan McGrew, \& Serway, 2010)). Fenomena ini dapat diinterpretasikan bahwa balok $A$ menolak ajakan tali $a_{2}$ dan lebih senang tetap tinggal bersama tali $a_{1}$ sedangkan balok $B$ lebih senang meninggalkan tali $b_{1}$ dan pergi bersama tali $b_{2}$. Dalam hal ini tali $a_{1}$ dan $b_{1}$ dianalogikan sebagai rumah bagi orang pertama sedangkan tali $a_{2}$ dan $b_{2}$ dianalogikan sebagai orang kedua.

Penanaman karakter terkait dengan pembahasan fisika di atas adalah bahwa kita dapat membandingkan prilaku "benda mati" (dalam hal ini balok $A$ dan $B$ ) dengan manusia. Selama ini, secara umum kita tidak peduli bahwa pada hakekatnya benda-benda atau "benda mati" pun memperlihakan prilaku seperti prilaku-prilaku yang selama ini dianggap hanya dimiliki oleh manusia atau mahluk hidup. Jika "benda mati" saja memiliki dapat bersikap menolak atau menurut terhadap suatu stimulus, bagaimana dengan kita sebagai manusia dengan predikat ciptaan Allah SWT (Tuhan) yang paling sempurna. Implementasi fenomena ini dalam pembelajaran adalah bahwa melalui pembahasan hukum I Newton (hukum kelembaman) secara implisit ataupun eksplisit kita dapat menanamkan karakter positif kepada mahasiswa.

Karakter positif yang terkait dalam hal ini adalah bahwa selaku pengajar (dosen maupun guru) sebaiknya menenpatkan pembelajar (mahasiswa atau siswa) secara bermartabat sehingga pembelajar juga memberi respon positif terhadap proses pembelajaran itu sendiri. Demikian pula prilaku sesama pembelajar sebaiknya saling menghargai satu dengan lainnya. Kesadaran bahwa respon orang lain atau lingkungan di sekitar kita bergantung pada jenis stimulus yang kita berikan terhadap orang atau lingkungan itu, secara implisit menyarankan agar kita harus memiliki rasa tanggung-jawab, hormat terhadap orang lain, empati, serta cinta terhadap lingkungan dan suka menolong ((Kemendiknas, 2010), (Mulyasa, 2012), (Zubaedi, 2012)).

\section{b. Hukum Lenz \& Induksi Elektromagnetik}

Menurut hukum Lenz, apabila dalam suatu kumparan konduktor mengalir arus listrik kemudian kuat arus listrik tersebut berubah maka dalam kumparan tersebut akan terjadi arus induksi (induksi diri) yang berarah sedemikian rupa sehingga menghasilkan medan magnet yang melawan perubahan medan magnet penyebabnya. Sementara induksi elektromagnetik lebih berfokus pada terjadinya arus listrik dalam suatu kumparan konduktor sebagai hasil dari induksi medan magnet. Jadi pada dasarnya fenomena hukum Lenz dan peristiwa induksi elektromagnetik memiliki kesamaan, yaitu terjadinya arus listrik dalam suatu kumparan hasil induksi oleh perubahan medan magnet. Perbedaannya adalah, jika dalam hukum Lenz sebagai induktor kumparan itu sendiri sedangkan pada peristiwa induksi elektromagnetik sebagai induktor sumber medan magnet dari benda lain, seperti batang magnet (Gambar 2) atau kumparan lain yang diberi arus listrik (Gambar 3) ((Halliday \& Resnick, 1978), (Tipler \& Mosca, 2008), (Gordon, dan McGrew, \& Serway, 2010)). 


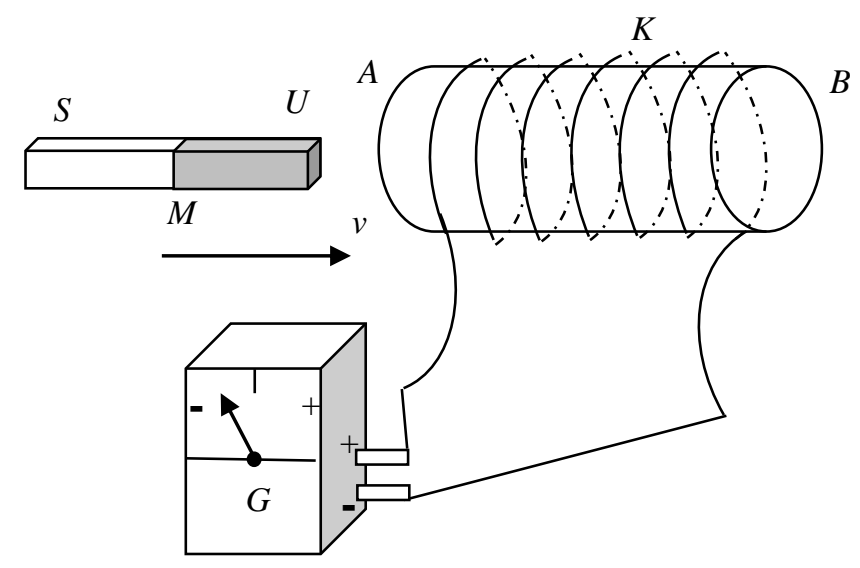

Gambar 2. Set percobaan induksi elektromagnetik dengan induktor batang magnet pada kumparan konduktor, batang magnet digerakkan ke kanan dengan laju $v$ sehingga jarum $\mathrm{G}$ menyimpang ke kiri

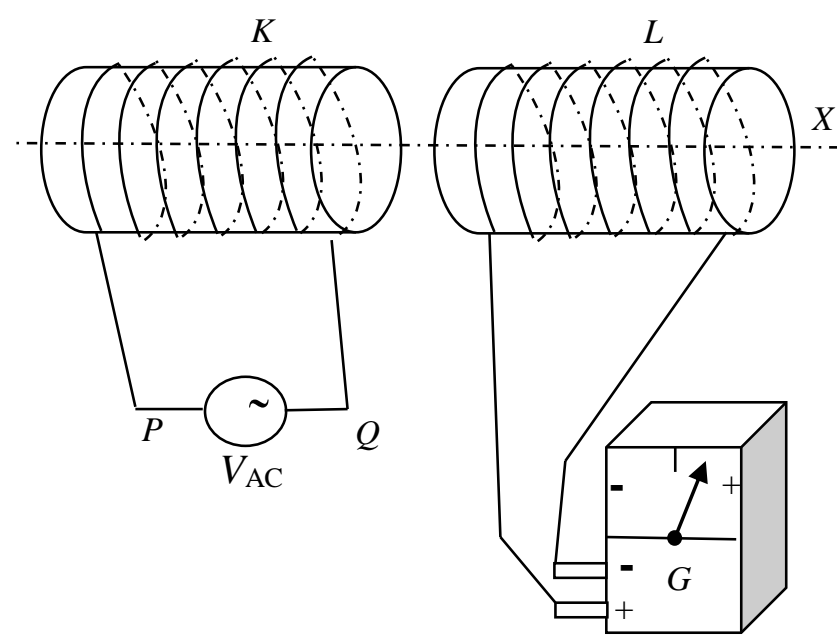

Gambar 3 Set percobaan induksi elektromagnetik dengan induktor kumparan $K$ berarus listrik AC pada kumparan konduktor, saat itu arus di $K$ arus dari $P$ ke Q dan semakin besar sehingga jarum $\mathrm{G}$ menyimpang ke kanan

Analisis lanjut hukum Lenz dan induksi elektromagnetik. Pada hukum Lenz arus induksi hanya terjadi apabila arus awal yang dialirkan dalam kumparan kekuatannya berubah sehingga kekuatan medan magnet induktor juga berubah. Hal serupa berlaku pada induksi elektromagnetik, yaitu sumber medan magnet induktor harus sedemikian rupa sehingga medan magnet induktor harus berubah kekuatan dan/atau orientasinya. Semenara itu, jika medan magnet induktor tidak berubah kekuatan maupun orientasinya maka arus induksi dalam kumparan itu tidak ada. Fenomena medan magnet induktor ini memperlihatkan bahwa arus induksi dalam kumparan itu sesungguhnya merupakan reaksi kumparan tersebut terhadap suatu aksi ((Halliday \& Resnick, 1978), (Tipler \& Mosca, 2008), (Gordon, dan McGrew, \& Serway, 2010)).

Penanaman karakter yang terkait: Dua fenomena di atas menunjukkan bahwa jika kekuatan dan/atau orientasi medan magnet yang ada dalam kumparan tersebut bersifat tetap baik kekuatan maupun orientasinya arus induksi tidak terjadi dalam kumparan tersebut. Jika induktor (medan magnet awal yang dihasilkan batang magnet atau arus listrik) dan kumparan konduktor masing-masing dianalogikan sebagai orang-pertama dan orangkedua, serta saat itu kedua orang tersebut tinggal bersama di rumah milik orang-kedua maka fenomena hukum Lenz dan induksi elektromagnetik tersebut dapat dimaknai seperti pada pembahasan dalam alinea di bawah ini.

Saat medan magnet induktor tidak berubah kekuatan maupun orientasinya dianalogikan orangpertama berdiam atau melakukan kegiatan-kegiatan yang diperbolehkan oleh pemilik rumah (orangkedua) sehingga orang-kedua dapat menerima orangpertama itu untuk tetap tinggal di rumahnya. Tetapi ketika medan magnet induktor berubah kekuatan atau orientasinya dianalogikan bahwa orang-pertama melakukan kegiatan yang tidak diperbolehkan pemilik rumah (orang-kedua) sehingga orang-kedua mengusir orang-pertama. Dalam fenomena fisika 
tersebut, kumparan konduktor yang dianalogikan sebagai pemilik rumah mengeluarkan arus induksi yang arahnya sedemikian rupa sehingga arus tersebut menghasilkan medan magnet yang bersifat melawan perubahan medan magnet awal ((Halliday \& Resnick, 1978), (Tipler \& Mosca, 2008), (Gordon, dan McGrew, \& Serway, 2010)) yang dianalogikan sebagai orang-pertama yang tinggal di rumah orangkedua.

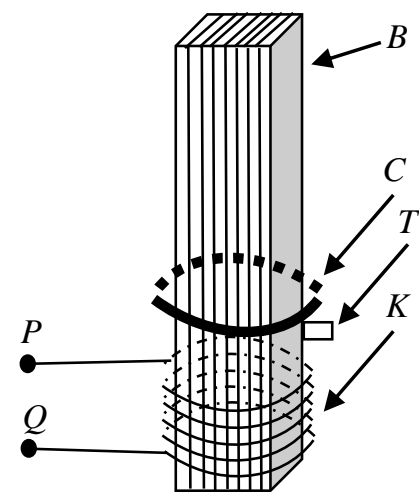

Gambar 4. Fenomena Cincin Terbang

Fenomena fisika dan penganalogian di atas dapat dikaitkan dengan karakter positif. Komponenkomponen karakter positif yang terkait antara lain rasa tanggung jawab, hormat terhadap orang lain, empati, dan kesabaran. Jika peristiwa ketua fenomena tersebut dibiarkan terjadi cukup lama dapat mengakibatkan kumparan menjadi panas. Jika dianalogikan dengan prilaku manusia, kenaikan suhu kumparan menandakan bahwa orang-kedua (pemilik rumah) tidak dapat menahan emosinya (marah)

Ditiup ke bawah

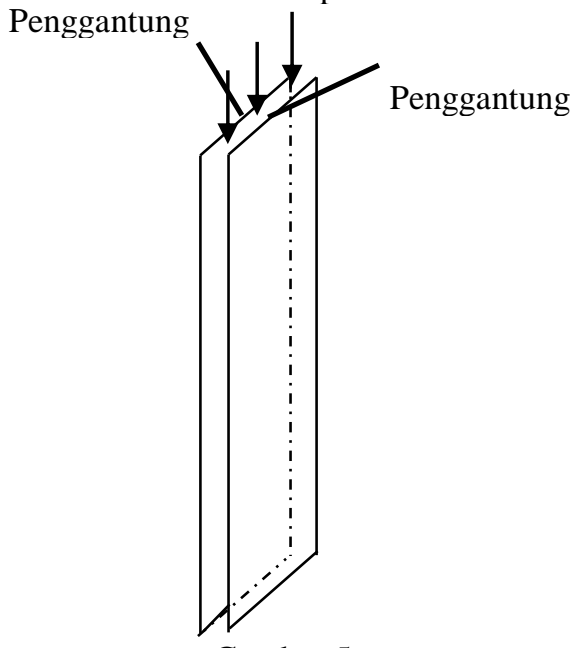

Gambar 5a sedangkan prilaku induktor mengubah kekuatan atau orientasinya dapat dianalogikan bahwa orang-pertama tersebut telah berbuat tidak/kurang mampu mengendalikan diri, cinta terhadap lingkungan sekitar. Fenomena fisika yang erat kaitannya dengan hukum Lenz adalah cincin terbang (Gambar 4).

Gambar 4 menunjukkan satu set percobaan induksi elektromagnetik yang terdiri atas sebuah batang logam lunak $B$, yaitu batang logam yang mudah terinduksi menjadi magnet tetapi juga mudah hilang sifat magnetnya dan batang tersebut dibuat berlapis-lapis, kumparan $K$ yang berujung $P$ dan $Q$, serta sebuah cincin konduktor $C$ di atas penahan $T$ dan mudah bergerak naik dalam batang $\operatorname{logam} B$. Andaikan ujung $P$ dan $Q$ duhubungkan pada suatu sumber tegangan bolak balik $V$ maka cincin konduktor tersebut akan terlempat ke atas meninggalkan batang logam.

\section{c. Hukum Bernaulli}

Menurut hukum Bernaulli tekanan fluida bergantung pada keadaan geraknya. Jika fluida tersebut mengalir semakin cepat maka tekanan pada fluida tersebut semakin kecil. Jadi jika terdapat dua kelompok fluida dengan kelajuan aliran berbeda menyebabkan perbedaan tekanan pada setiap titik dalam kedua kelompok fluida tersebut. Fenomena ini antara lain dijadikan sebagai dasar untuk pembangkit daya angkat pesawat terbang atau helicopter. Hubungan besaran tekanan dan kelajuan fluida ini sejalan dengan Halliday \& Resnick (1978), Tipler \& Mosca (2008), Gordon, dan McGrew (2010), serta Serway (2010).

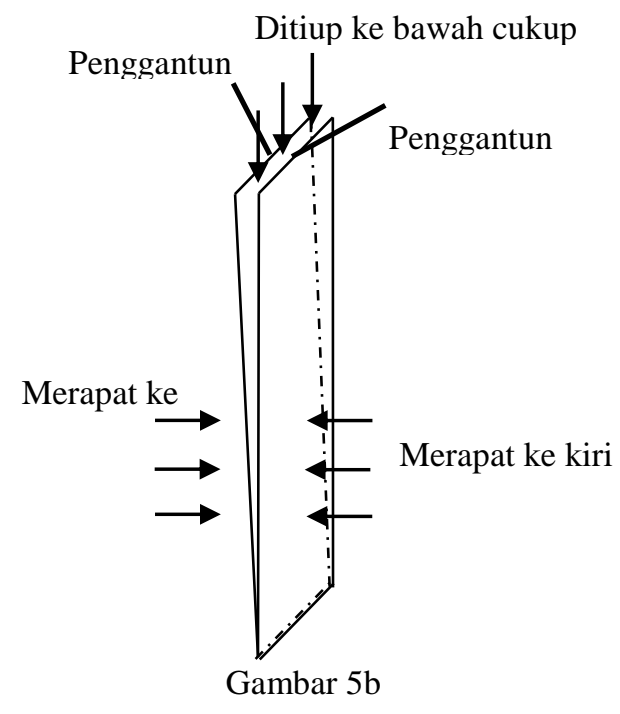

Gambar 5 Fenomena Kertas Merapat Sebelum Ditiupkan Udara (a) dan Saat Ditiupkan Udara melalui BagianTengahnya (b) 


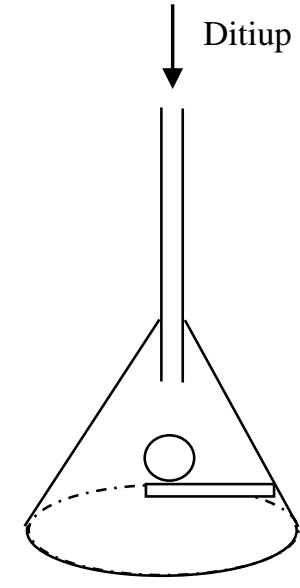

Gambar 6a

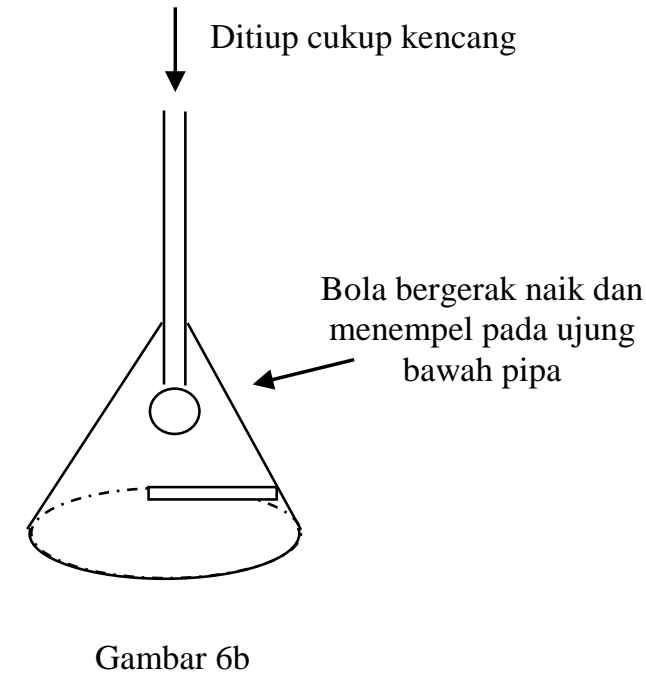

Gambar 6b

Gambar 6 Fenomena Bola Plastik dalam Corong Sebelum Ditiupkan Udara (a) dan Saat Ditiupkan Udara dari Atas ke Bawah (b)

Gambar 5 dan 6 memperlihatkan fenomena fisika sederhana yang merupakan contoh dari implementasi hukum Bernoulli di atas. Gambar 5 memperlihatkan fenomena dua lembar kertas berposisi digantung terpisah sejauh sekitar $2,5 \mathrm{~cm}$. Keadaan awal tidak ada udara ditiupkan (Gambar 5a) berikutnya dari bagian atas ditiupkan udara melalui bagian tengah kedua kertas tersebut (Gambar 5b). Pada gambar 5b terlihat bagian kertas yang tidak dipegang (dijepit) bergerak saling mendekat dan gerakan mendekat ini semakin kuat apabila kecepatan udara yang ditiupkan ditambah.

Analisis lanjut hukum Bernoulli berkenaan dengan fenomena pada Gambar 6. Pada Gambar 6a udara dalam corong dan dalam pipa dalam keadaan berdiam. Seperti pada Gambar 5a, berdasarkan hukum Bernoulli bahwa tekanan di setiap titik dalam udara dipengaruhi oleh keadaan gerak udara tersebut. Jika udara itu bergerak tekanan udaranya lebih rendah dan semakin cepat gerakan udara itu semakin rendah pula tekanannya. Dalam fenomena Gambar 6a, udara dalam corong dan dalam pipa berdiam sehingga tekanan udara di titik-titik itu sama. Hal ini menyebabkan fenomena Gambar 6a dapat terjadi, yaitu bola dapat berdiam di atas batang penopang.

Pada Gambar 5b, udara dalam corong dipaksa mengalir ke bawah sebagai akibat tiupan yang diberikan dari atas melalui pipa. Namun demikian, mengingat sistem pipa-corong merupakan satu kesatuan saluran udara sedangkan diameter pipa jauh lebih kecil daripada diameter corong maka berdasarkan azas kontiuitas aliran udara dalam pipa lebih cepat daripada dalam corong. Selain itu, diameter corong dari bagian atas ke bawah adalah semakin besar sehingga beradasarkan azas tersebut aliran udara dalam corong pada bagian atas ke bawag adalah semakin lambat karena diameter atau penampannya semakin besar. Hal ini mengakibatkan tekanan udara dalam pipa lebih rendah daripada dalam corong. Ssementara itu, dalam corong, dari atas ke bawah udaranya semakin besar karena kecepatan udara alirannya dari atas corong ke bawah semakin lambat. Perbedaan tekanan ini menyebabkan gaya dorong pada bola, yaitu berarah ke atas. Penjelasan fenomena ini sejalan dengan Halliday \& Resnick (1978), Tipler \& Mosca (2008), Gordon dan McGrew (2010), serta Serway (2010).

Penanaman karakter yang terkait: Fenomena fisika sebagaimana ditampilkan dalam Gambar 5 dan 6 pada dasarnya memiliki kemiripan dengan fenomena pada Gambar 1 tentang hukum kelembaman, Gambar 2, 3, dan 4 tentang hukum Lenz dan induksi elektromagnetik. Semua fenomena Gambar 1 sampai dengan 6 tersebut pada dasarnya memiliki kesamaan. Jika gaya aksi pada Gambar 1, induktor pada Gambar 2, 3, dan 4, serta tiupan pada Gambar 5 dan 6 dianalogikan sebagai orang-pertama sedangkan balok $A$ dan $B$ pada Gambar 1, medan magnet yang dihasilkan dari arus induksi pada Gambar 2, 3, dan 4, serta gerakan kertas pada Gambar 5 dan gerakan bola pada Gambar 6 dianalogikan sebagai orang-kedua maka pada keenam fenomena tersebut dapat dikatakan bahwa orangpertama melakukan tindakan aksi kepada orangkedua dan orang-kedua ini melakukan tindakan reaksinya. Selanjutnya, berdasar pada fakta-fakta dalam keenam fenomena tersebut dapat dianalogikan bahwa ketika orang-pertama dalam melakukan aksinya secara perlahan atau "persuasif" orang-kedua dapat dikatakan tidak memberi reaksi tetapi apabila aksi orang-pertama dilakukan secara cepat orangkedua memberi reaksi.

Deskripsi dalam alinea di atas dapat diinterpretasikan bahwa benda-benda fisika, dalam fenomena Gambar 1 sampai dengan 6, seperti balok, kumparan konduktor, cincin konduktor, kertas, dan 
bola plastik atau secara umum benda-benda yang tidak bernyawa atau "benda mati" memiliki prilaku seperti mahluk hidup. Ketika aksi-aksi yang berupa gaya tarik (pada Gambar 1), gerak batang magnet (pada Gambar 2), arus listrik (pada Gambar 3 dan 4), serta tiupan (pada Gambar 5 dan 6) bekerja secara perlahan atau "persuasif" benda-benda "mati" di atas tidak memberikan reaksi. Namun demikian, ketika aksi-aksi di atas dilakukan secara cepat benda-benda "mati" ini memberi reaksi yang bersifat menentang reaksi yang diterimanya. Dalam hal "benda mati" tidak memberi reaksi terhadap suatu aksi dapat diinterpretasikan bahwa benda tersebut dapat menerima aksi-aksi yang datang tetapi ketika "benda mati" itu bereaksi dapat diartikan bahwa benda tersebut tidak menerima atau "tidak senang" terhadap reaksi yang diterimanya sehingga berusaha untuk melawannya.

Analogi dari makna dari pembahasan dua alinea di atas memperlihatkan bahwa ketika pendidik (dosen atau guru) ingin mengubah prilaku pembelajar (mahasiswa atau siswa) sebaiknya dilakukan secara "persuasif" sehingga ada kecenderungan pembelajar akan mengalami perubahan prilaku seperti yang diharapkan pendidik. Sebaliknya, jika pendidik dalam upaya mengubah prilaku pembelajar dilakukan secara "cepat" ada kecenderungan pembelajar tidak mengalami perubahan prilaku seperti yang diharapkan bahkan dapat terjadi hal sebaliknya, yaitu pembelajar berubah prilakunya menuju arah yang berlawanan dengan harapan. Upaya mengubah prilaku pembelajar secara "cepat" dapat diinterpretasikan pendidik melakukan upaya tersebut secara paksa, kurang menyenangkan, kurang menghargai hak-hak pembelajar, kurang memperhatikan keinginan pembelajar, dan sebagainya. Sementara itu, upaya mengubah prilaku pembelajar secara "persuasif" dapat diinterpretasikan pendidik membelajarkan pembelajar secara sabar, memperhatikan kebutuhan pembelajar, menghargai hak-hak pembelajar, bahkan menyenangkan.

\section{Penutup}

\section{A. Kesimpulan}

Peluncuran kurikulum 2013 merupakan salah satu upaya menekan perilaku negatif yang ada dan menekan kemungkinan tumbuhnya perilaku tersebut pada para pembelajar yang sedang menempuh pendidikan. Pembahasan dalam Perkuliahan Fisika Dasar 1, khususnya hukum I Newton tentang gerak, hukum Lenz, induksi elektromagnetik, dan hukum Bernoulli tentang tekanan fluida mengalir memperlihatkan bahwa dalam konsep-konsep tersebut tersirat hubungan aksi-reaksi antara bendabenda. Dalam konteks pembelajaran, hubungan interaksi benda-benda dalam fisika dapat dianalogikan sebagai interaksi pendidik dengan pembelajar. Selain itu, fenomena bagaimana suatu reaksi dari sebuah benda terhadap adanya aksi dari benda lain terhadapnya dapat dianalogikan sebagai prilaku pendidik terhadap pembelajar.

Jenis reaksi dari benda yang sangat bergantung pada bagaimana sifat aksi yang diterimanya dapat dianalogikan bahwa karakter pembelajar dapat dibentuk oleh prilaku pendidiknya. Selain itu, melalui analisis fenomena-fenomena fisika dapat ditunjukkan bahwa benda-benda fisika memperlihatkan sifat yang dapat dianalogikan sebagai prilaku atau karakter yang selama ini dikenal hanya dimiliki oleh manusia sebagai mahluk yang paling sempurna. Karakterkarakter positif yang dapat ditanamkan kepada pembelajar melalui pembahasan fenomena fisika dan pendekatan analogi antara lain sifat kejujuran, tanggung-jawab, rasa hormat terhadap orang lain, empati, pengendalian diri, kerendahan hati, kesabaran, pantang putus asa, tekun, kecintaan terhadap lingkungan sekitar, dan suka menolong. Dalam menanamkan karakter positif kepada pembelajar perlu menjadikan nilai-nilai positif sebagai pembiasaan dalam pemikiran, perasaan, dan dalam tindakan.

\section{B. Saran}

Pada dasarnya benda dengan sifat-sifat reaktifnya dapat dianalogikan bahwa benda memiliki "perasaan" seperti mahluk hidup bahkan sperti manusia. Karenanya, para pendidik dalam membahas fenomena-fenomena fisika atau fenomena alam pada umumnya sebaiknya mampu mengambil sifat-sifat positif benda dan mampu menginterpretasikannya kedalam karakter-karakter positif yang selanjutnya menjadikan karakter-karakter tersebut sebagai pembiasaan dalan pikiran, perasaan, dan tindakan bagi para pembelajar.

\section{REFERENSI}

[1] Gordon, J. R., McGrew, R. V., \& Serway, R. A. (2010). Physics for Scientists and Engineers, eighth edition volume 1. USA: Cengage Learning, Inc.

[2] Halliday, D. \& Resnick, R. (1978). Physics part 1 $\&$ 2, Third Edition. Canada: John Wiley \& Sons. Inc.

[3] Kemendiknas (2010). Pembinaan Pendidikan Karakter di Sekolah Menengah Pertama. Jakarta

[4] Knight, R. D. (2008). Physics for Scientists and Engineers, 2nd edition. USA: Pearson Addison Wisley.

[5] Kompas (2009). Perkelahian Pelajar. Diunduh di kompas.com pada tanggal 5 Januari 2015.

[6] Kompas (2009). Audi Tewas karena Perkelahian, Disdik Haramkan Geng Sekolah. Diunduh di kompas.com pada tanggal 5 Januari 2015. 
[7] Kosasih, E., (2014). Strategi Belajar dan Pembelajaran, Implementasi Kurikulum 2013. Bandung: Penerbit Yrama Widya.

[8] Mulyasa, H. E., (2012). Manajemen Pendidikan Karakter. Jakarta: PT Bumi Aksara.

[9] Podolefsky, N., (2004). The Use of Analogy in Physics Learning and Instruction. University of Colorado.

[10] Rokhmat, J., (2014). Penggunaan Paradigma Gaya-Reaksi dan Pendekatan Analogi untuk Meningkatkan Pemahaman Konsep Gaya Gesek bagi Mahasiswa Calon Guru Fisika, (Studi Kasus Perkuliahan Fisika Dasar I). Unram: Jurnal Pendidikan Matematika dan IPA Pijar, September.

[11] Tipler, P. A. \& Mosca, G.(2008). Physics for Scientists and Engineers, Sixth edition. New York: W H Freeman and Company.

[12] Zubaedi, (2012). Desain Pendidikan Karakter; Konsepsi dan Aplikasinya dalam Lembaga Pendidikan. Jakaarta: Kencana Prenada Media Group.

\section{Biografi Penulis}

Joni Rokhmat, lahir di Wonosobo Jawa Tengah tanggal 5 Pebruari 1962, anak kedua dari dua bersaudara, dari pasangan Ayahanda Sarwadi Muhto dengan Ibunda Bonilah.

Riwayat Pendidikan. Menempuh pendidikan formal di SD Kesatrian I, lulus tahun 1976, SMPN I Cimahi, lulus tahun 1980, SMAN I Wonosobo, lulus 1984. Program Studi Pendidikan Fisika, jenjang D3 IKIP Bandung, lulus tahun 1987, Program Studi Pendidikan Fisika, jenjang S1 IKIP Bandung, lulus tahun 1990, Jurusan Fisika, jenjang S2 Institut Teknologi Bandung, lulus tahun 1999. Tahun 2009 mengikuti Program Doktor di Sekolah Pasca Sarjana Program Pendidikan IPA, konsentrasi Pendidikan Fisika, Universitas Pendidikan Indonesia.
Riwayat Pekerjaan. Dosen Program Studi Pendidikan Fisika di Fakultas Keguruan dan Ilmu Pendidikan Universitas Mataram sejak tahun 1992 sampai sekarang, Ketua Seksi Workshop UPT MIPA Universitas Mataram tahun 2001 sampai 2007, Sekretaris Jurusan Pendidikan MIPA, FKIP Universitas Mataram tahun 2005 sampai 2008, Anggota Tim Persiapan Program Sertifikasi, FKIP Unram - BPG Mataram, Tahun 2000, Panitia Pelaksana, Instruktur Pendidikan, Pelatih Kualifikasi di Provinsi Nusa Tenggara Barat (NTB), BPG Mataram, tahun 2002, Anggota Tim Penilai Usulan Kredit Point Tingkat Jurusan PMIPA, FKIP Unram, 2001 - 2005, Anggota Tim Penilai Proposal Penelitian FKIP Unram, 2002 - 2006, Anggota Tim Penyusun Kurikulum SD Model tahun 2006, dan Anggota pelaksana Tim Evaluasi Good Practices, kerjasama Inonesia - UNICEF Tahun 2007.

Aktif Menulis dan Meneliti terkait dengan pengembangan aneka alat permainan edukatif untuk pembelajaran di SD dari tahun 2001 hingga sekarang. Penelitian yang telah dilakukan: (1) Pengembangan Prototype Permainan Edukatif Model Kartu Kuartet Untuk Pembelajaran Sains Fisika Di Sekolah Dasar, Penelitian Pendidikan Dana SPP/DPP , Universitas Mataram, 2007; (2) Pengembangan "Taman Edukatif" Untuk Pembelajaran Sain IPA Elementer Pada Siswa Sekolah Dasar., Penelitian Hibah Bersaing, 2007; (3) Perancangan "Taman Edukatif" Tingkat Satuan Kelas Untuk Pembelajaran di Sekolah Dasar, Unram: Laporan Penelitian Hibah Bersaing, 2009; (4) Perancangan "Kit Permainan Edukatif" Tingkat Satuan Kelas Untuk Pembelajaran di Sekolah Dasar, Unram: Laporan Penelitian Hibah Bersaing, 2009. Tahun 2013 mengajukan penelitian hibah strategi nasional dan kegiatan pengabdian masyarakan terkait dengan pengembangan kemampuan berpikir kausalitas and analitik sebagai hasil penelitian doktoralnya. 